\title{
Australian Journal of \\ Physiological potential of soybean industrially treated with different spray volumes and dry powder
}

\author{
Julia Abati ${ }^{1}$, Cristian Rafael Brzezinski ${ }^{2}$, Claudemir Zucareli ${ }^{3}$, Flávia Werner ${ }^{3 *}$, Ademir Assis Henning ${ }^{4}$, \\ Fernando Augusto Henning ${ }^{4}$
}

\author{
${ }^{1}$ Agronomic Sciences Department, State University of Maringá, Umuarama Campus, Estrada da Paca, Zip Code: \\ 87507-190, Umuarama, PR, Brazil \\ ${ }^{2}$ Research Department, GDM Brazil' Genetics S.A., Avenue Anísio Alves Costa, 1860, Downtown, Zip Code: 77500 - \\ 000, Porto Nacional, TO, Brazil \\ ${ }^{3}$ Agronomy Department, State University of Londrina, Highway Celso Garcia Cid 445 Km 380, Zip Code: 86057-970, \\ Londrina, PR, Brazil \\ ${ }^{4}$ Embrapa Soybean, Brazilian Agricultural Research Corporation, Highway Carlos João Strass, Warta District, Zip \\ Code: 86001-970, Londrina, PR, Brazil
}

*Corresponding author: flawerner6@gmail.com

Abstract

\begin{abstract}
The industrial treatment of seeds has favored the development of new technologies such as the use of dry powder. It has made application of spray volumes higher than those used in the conventional treatment. Therefore, this study aimed to assess the effect of industrial treatments at different spray volumes with and without application of dry powder on physiological quality of soybean seeds. A completely randomized experimental design was performed with four replications in a $5 \times 2$ factorial arrangement for cultivars BRS 359 RR and BRS 284. The factors were five spray volumes $\left(0,600,1200,1800\right.$ and $2400 \mathrm{~mL}$. $\left.100 \mathrm{~kg}^{-1}\right)$ with and without the application of dry powder. The products used to obtain the volumes were fungicides (carbendazim + thiram); insecticides (imidacloprid + thiodicarb); nematicide (abamectin); micronutrients (cobalt, molybdenum and zinc); polymer (peridiam); biostimulant (kinetin + gibberellic acid + 4-indol-3-ylbutyric acid) and inoculant (Bradyrhizobium japonicum). The physiological quality of the seeds was determined by the following assessments: germination, first count of germination test, seedling emergence in sand, emergence speed index, and total length of the seedling shoot and root. The results showed that increased spray volume associated with the application of dry powder in seed treatment reduced the physiological quality of soybean seeds, and spray volumes up to $1200 \mathrm{~mL} 100 \mathrm{~kg}^{-1}$ in seed treatment without the application of dry powder do not impact the emergence and establishment of soybean seedlings.
\end{abstract}

Keywords: Fungicides, Germination, Glycine max (L.) Merrill, Insecticides, Vigor.

Abbreviations: G_germination; FCG_first count of germination test; EM_seedling emergence in sand; ESI_emergence speed index; STL_total length of seedlings; SL_shoot length and RL_root length. F_fungicides (carbendazim + thiram); I_insecticides (imidacloprid + thiodicarb); N_nematicide (abamectin); M_micronutrients (cobalt, molybdenum and zinc); P_polymer (peridiam); B_biostimulant (kinetin + gibberellic acid, such as GA3 + 4-indole-3-ylbutyric acid) and IN_inoculant (Bradyrhizobium japonicum).

Introduction

Seed is a basic and vital input for sustained growth in agricultural productivity. About ninety percent of the food crops are grown from seed (Anwar et al., 2013; Sharma et al., 2015). Seeds must have high quality and excellent health, physical, genetic and physiological characteristics. The physiological attributes involve changes in seed metabolic activities to express its potential through germination, vigor and longevity (Zorato and Henning, 2001; Marcos Filho, 2015).

Pests and diseases, among other factors, can impact the quality and performance of most crops (Barros et al., 2005; Conceição et al., 2014; Reznikov et al., 2016). Associated with adverse climatic conditions, they may compromise the early development of crops in the field, with impact on germination and seedling emergence, particularly in soybean. Therefore, treating seeds with chemical products is essential to control seed pathogens present in the soil, which ensures the establishment of uniform plant stands, and reduce the possibility of introduction of pathogens in non-infected areas through seeds (Mertz et al., 2009; Balardin et al., 2011; Abati et al., 2014).

Seed treatment is usually performed during pre-sowing, in the farmers' properties and in the seed resale store, with the aid of equipment for this specific purpose. However, with the latest technological advances in agriculture, seed producing companies have been using techniques to optimize logistics and maximize crop yield, such as the industrial seed treatment (IST). In this process, seeds are 
treated in the processing line and subsequently bagged and stored until sowing. IST combines the use of equipment and techniques with high efficiency and precision, allowing the use of new formulations and products containing fungicides, insecticides, polymers, nematicides, biostimulants, micronutrients and inoculants in the same treatment (Brzezinski et al., 2015).

The association of these products may result in spray volumes higher than $600 \mathrm{~mL} 100 \mathrm{~kg}^{-1}$ of seeds. This volume is recommended in conventional treatment that mostly applies dry powder and water. However, there are currently new formulations based on other products, e.g. dyes and polymers (Krzyzanowski et al., 2007; França Neto et al., 2015).

The application of a higher volume of chemicals may affect the seed coat, rupturing cell membranes and accelerate the seed imbibition with negative effects on the physiological potential of the seeds. In a study on soybean seeds, Segalin et al. (2013) found that spray volumes up to $1400 \mathrm{~mL} 100 \mathrm{~kg}^{-}$

${ }^{1}$ of seeds did not reduce physiological quality.

New technologies have been developed to increase the efficiency of the process, such as the use of a dry powder, thanks to the dissemination of the use of industrial seed treatment. Uniform and faster drying of seeds can be achieved with this product. Also, larger spray volumes can be used in industrial treatment to improve sowing and even replace the use of graphite.

Therefore, studies on the interaction between spray volumes and the use of dry powder in seed industrial treatment and their effect on the physiological quality of seeds are needed. The present study aimed to assess the effect of different spray volumes on the physiological quality of soybean seeds with and without application of dry powder, using industrial treatments.

\section{Results and Discussions}

The summary of variance analysis for interaction between the spray volumes and the dry powder and the separate effects of each volume for both cultivars are shown in Table 2 , as well as the means observed for the significant comparisons for the separate effect of the dry powder agent.

\section{Germination}

There were lower germination rates for the seeds of cultivar BRS 359 RR treated with dry powder, which were below the minimum standard requirement for commercialization (Table 3). In seeds not treated with dry powder, lower germination rates were detected only in treatments with volumes equal to or greater than $1200 \mathrm{~mL} 100 \mathrm{~kg}^{-1}$. However, only the 1800 and $2400 \mathrm{~mL} 100 \mathrm{~kg}^{-1}$ volumes showed germination percentage values below $80 \%$, which is minimum standard required for the commercialization of soybean seeds (Mapa, 2013). Thus, seed industrial treatments with spray volumes up to $1200 \mathrm{~mL} 100 \mathrm{~kg}^{-1}$, without dry powder does not impact the commercialization of these seeds.

Lower germination rates as a result of high spray volumes may be associated with damage to the seed coat after industrial treatment. According to França Neto et al. (2015), soybean seeds submitted to high spray volumes may encounter detached seed coat, with impact on their quality, particularly in seeds with mechanical damage and low vigor. Poorer quality can be caused by the exposure of vital structures of the seeds, such as the embryonic axis, to external agents that may impair the germination process. In addition, high spray volumes may accelerate the imbibition of soybean seeds, leading to internal stresses that may break cell membranes. This interferes with the reorganization of cellular organelles, particularly the membranes, with exudation of cell contents, resulting in seed damage and reduce in germination rates (Toledo et al., 2010; Marcos Filho, 2015).

In cultivar BRS 359 RR, except for the control treatment (volume 0 ), the seeds not-treated with dry powder showed higher germination rates compared to the seeds treated with dry powder (Table 3). This difference may be related to the properties of the dry powder and its interaction with the spray volumes, since there was no significant difference in the control treatment. According to Clifton (1985), talc has several properties, including high oil and grease absorption capacity and a hydrophilic behavior. Thus, the application of dry powder on the seeds may have intensified the chemicals absorption by the seed coat and embryo, mainly due to the properties of the different vehicles used in the treatment. This causes greater seed coat detachment, disorganization of the membranes and consequent reduction in germination rates.

For germination of cultivar BRS 284, there was a separate effect for the investigated factors (Table 2). The seeds treated with spray volumes of $1200 \mathrm{~mL} .100 \mathrm{~kg}^{-1}$ and higher showed lower germination rates (Table 4). Regarding the effect of the dry powder, higher germination rates were observed in the seeds not treated with the dry powder compared to the others (Table 2).

\section{First germination count}

The vigor was determined by the test of first germination count, in which interaction between the investigated factors in both cultivars was detected (Table 2). For the seeds of cultivar BRS 359 RR treated with dry powder, the higher spray volumes reduced the speed of germination and vigor (Table 3). BRS 359 RR seeds not treated with a dry powder and the seeds treated and not treated with dry powder of cultivar BRS 284 showed lower germination. The lower rates were observed with the application of volumes of $1200 \mathrm{~mL}$ $100 \mathrm{~kg}^{-1}$ or higher. Brzezinski et al. (2017) found that increased spray volumes reduce the physiological quality of the seeds, particularly in seeds with low vigor.

Regarding the dry powder agent, in BR 359 RR differences were observed only for 600,1200 and $2400 \mathrm{~mL} 100 \mathrm{~kg}^{-1}$ volumes, and in BRS 284, with application of 1200 and 2400 $\mathrm{mL} .100 \mathrm{~kg}^{-1}$ volumes, while better results reported for seeds treated without the use of dry powder (Table 3).

\section{Seedling emergence in sand}

Regarding seedling emergence in sand in both cultivars we found that increased spray volumes reduced the seedling emergence values in dry powder treated seeds (Table 3). The seeds of BRS 359 RR and BRS 284 not treated with dry powder, only the application of a volume of $2400 \mathrm{~mL} 100 \mathrm{~kg}$ 1 and volumes of 1800 and $2400 \mathrm{~mL} 100 \mathrm{~kg}^{-1}$ differed significantly from the control treatment, respectively. 
Table 1. Products and doses used in the industrial treatment of soybean seeds to obtain different spray volumes $(0,600,1200$,

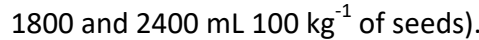

\begin{tabular}{|c|c|c|c|c|c|c|c|c|}
\hline Volumes & $\mathrm{F}^{1}$ & 1 & $\mathrm{~N}$ & $\mathrm{M}$ & $\mathrm{P}$ & B & IN & Total \\
\hline 0 (control sample) & - & - & - & - & - & - & - & 0 \\
\hline 600 & $200^{2}$ & 300 & 100 & - & - & - & - & 600 \\
\hline 1200 & 200 & 300 & 100 & 400 & 200 & - & - & 1200 \\
\hline 1800 & 200 & 300 & 100 & 400 & 200 & 600 & - & 1800 \\
\hline 2400 & 200 & 300 & 100 & 400 & 200 & 800 & 400 & 2400 \\
\hline
\end{tabular}

Table 2. Summary of the analysis of variance for the physiological quality of seeds of two soybean cultivars (BRS 359 RR and BRS 284), as a result of seed industrial treatment with different volumes of spray and application of dry powder.

\begin{tabular}{|c|c|c|c|c|c|c|c|c|}
\hline \multicolumn{9}{|c|}{-------------- BRS 359 RR -------------- } \\
\hline & & \multicolumn{7}{|c|}{ Mean Squares } \\
\hline S.V. & G.L. & $\mathrm{G}$ & FCG & EM & ESI & STL & $\mathrm{SL}$ & $\mathrm{RL}$ \\
\hline Volume & 4 & $656.1^{* *}$ & $1835.7^{* *}$ & $205.9 * *$ & $97.6 * *$ & $25.2 * *$ & $1.63^{* *}$ & $16.49 * *$ \\
\hline Dry & 1 & $774.4^{* *}$ & $490.0 * *$ & $1254.4^{* *}$ & $92.5^{* *}$ & $3.13^{*}$ & $0.03^{\mathrm{ns}}$ & $2.80^{*}$ \\
\hline Vol*Dry & 4 & $137.4 * *$ & $314.0 * *$ & $133.3^{* *}$ & $23.8 * *$ & $3.0 * *$ & $0.12^{\mathrm{ns}}$ & $2.00 *$ \\
\hline Error & 30 & 31.5 & 25.5 & 17.5 & 1.77 & 0.64 & 0.11 & 0.52 \\
\hline Mean & - & 75.0 & 58.0 & 85.0 & 20.4 & 13.4 & 5.2 & 8,1 \\
\hline CV (\%) & - & 7.5 & 8.7 & 4.9 & 6.5 & 6.0 & 6.5 & 8.9 \\
\hline Dry powder & \multicolumn{8}{|c|}{ Averages } \\
\hline With & & 71.0 & 54.0 & 79.0 & 18.9 & 13.1 & 5.2 & 7.8 \\
\hline Without & & 80.0 & 61.0 & 90.0 & 21.9 & 13.7 & 5.3 & 8.4 \\
\hline \multicolumn{9}{|c|}{ 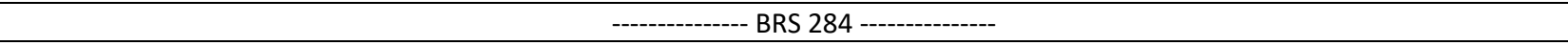 } \\
\hline S.V. & G.L. & $\mathrm{G}$ & FCG & EM & ESI & STL & $\mathrm{SL}$ & $\mathrm{RL}$ \\
\hline Volume & 4 & $1565.1^{* *}$ & $2128.0^{* *}$ & $114.8^{* *}$ & $34.1^{* *}$ & $23.2^{* *}$ & $0.97 * *$ & $20.6^{* *}$ \\
\hline Dry & 1 & $198.0 * *$ & $164.0^{*}$ & $119.0^{* *}$ & $7.7^{*}$ & $20.3^{* *}$ & $0.38^{\mathrm{ns}}$ & $26.5^{* *}$ \\
\hline Vol*Dry & 4 & $33.6^{\mathrm{ns}}$ & $92.6^{*}$ & $24.5^{* *}$ & $8.7^{* *}$ & $13.6^{* *}$ & $1,12 * *$ & $8.06 * *$ \\
\hline Error & 30 & 25.2 & 26.4 & 2.5 & 1.6 & 2.1 & 0.12 & 1.67 \\
\hline Mean & - & 77.0 & 68.0 & 94.0 & 24.9 & 14.6 & 5.3 & 9.3 \\
\hline CV (\%) & - & 6.5 & 7.5 & 1.7 & 5.1 & 9.9 & 6.7 & 13.8 \\
\hline Dry powder & \multicolumn{8}{|c|}{ Averages } \\
\hline With & & $75.0 \mathrm{~b}$ & 66.0 & 92.0 & 24.7 & 13.6 & 5.0 & 8.5 \\
\hline Without & & 79.0 a & 71.0 & 95.0 & 25.4 & 15.2 & 5.2 & 9.9 \\
\hline
\end{tabular}

Table 3. Germination (G), first count of germination test (FCG), seedling emergence in sand (EM) and emergence speed index (ESI) of soybean seeds from cultivars BRS 359 RR and BRS 284, treated with different spray volumes $(0,600,1200,1800$ and $2400 \mathrm{~mL}$. $100 \mathrm{~kg}^{-1}$ of seeds), and with and without application of a dry powder agent.

\begin{tabular}{|c|c|c|c|c|c|c|c|c|}
\hline \multicolumn{9}{|c|}{--------------- BRS 359 RR --------------- } \\
\hline \multirow{2}{*}{ Volumes } & \multicolumn{2}{|c|}{ G (\%) } & \multicolumn{2}{|c|}{ FCG $(\%)$} & \multicolumn{2}{|l|}{ EM (\%) } & \multicolumn{2}{|c|}{ ESI } \\
\hline & With & Without & With & Without & With & Without & With & Without \\
\hline 0 & $89 \mathrm{Aa}$ & $89 \mathrm{Aa}$ & $79 \mathrm{Aa}$ & $82 \mathrm{Aa}$ & $92 \mathrm{Aa}$ & $95 \mathrm{Aa}$ & $26.8 \mathrm{Aa}$ & $24.3 \mathrm{Ab}$ \\
\hline 600 & $72 \mathrm{Bb}$ & $87 \mathrm{ABa}$ & $60 \mathrm{Bb}$ & $74 \mathrm{Aa}$ & $83 \mathrm{Bb}$ & $92 \mathrm{ABa}$ & $20.0 \mathrm{Bb}$ & $25.0 \mathrm{Aa}$ \\
\hline 1200 & $72 \mathrm{Bb}$ & $81 \mathrm{BCa}$ & $50 \mathrm{Cb}$ & $64 \mathrm{Ba}$ & $78 \mathrm{BCb}$ & $89 \mathrm{ABa}$ & $16.9 \mathrm{Cb}$ & $20.8 \mathrm{Ba}$ \\
\hline 1800 & $62 \mathrm{Cb}$ & $74 \mathrm{Ca}$ & $46 \mathrm{Ca}$ & $45 \mathrm{Ca}$ & $72 \mathrm{Cb}$ & $87 \mathrm{ABa}$ & $16.1 \mathrm{Cb}$ & $20.6 \mathrm{Ba}$ \\
\hline 2400 & $60 \mathrm{Cb}$ & $72 \mathrm{Ca}$ & $36 \mathrm{Db}$ & $40 \mathrm{Ca}$ & $72 \mathrm{Cb}$ & $84 \mathrm{Ba}$ & $14.6 \mathrm{Cb}$ & $18.9 \mathrm{Ba}$ \\
\hline CV (\%) & \multicolumn{2}{|c|}{7.5} & \multicolumn{2}{|c|}{8.7} & \multicolumn{2}{|l|}{4.9} & \multicolumn{2}{|c|}{6.5} \\
\hline \multicolumn{9}{|c|}{--------------- BRS 284 --------------- } \\
\hline \multirow{2}{*}{ Volumes } & \multicolumn{3}{|c|}{ FCG (\%) } & \multicolumn{2}{|c|}{ EM (\%) } & \multicolumn{3}{|c|}{ ESI } \\
\hline & \multicolumn{2}{|l|}{ With } & Without & With & \multicolumn{2}{|l|}{ Without } & With & Without \\
\hline 0 & \multicolumn{2}{|l|}{$86 \mathrm{Aa}$} & $89 \mathrm{Aa}$ & $98 \mathrm{Aa}$ & $98 \mathrm{Aa}$ & \multicolumn{2}{|r|}{$29.1 \mathrm{Aa}$} & $27.1 \mathrm{Ab}$ \\
\hline 600 & \multicolumn{2}{|l|}{$84 \mathrm{Aa}$} & $85 \mathrm{Aa}$ & $94 \mathrm{Bb}$ & $98 \mathrm{Aa}$ & \multicolumn{2}{|r|}{$26.2 \mathrm{Ba}$} & $25.6 \mathrm{Aa}$ \\
\hline 1200 & $57 \mathrm{Bb}$ & \multicolumn{2}{|c|}{$69 \mathrm{Ba}$} & $91 \mathrm{Bb}$ & $96 \mathrm{Aa}$ & \multicolumn{2}{|r|}{$23.1 \mathrm{Cb}$} & $24.9 \mathrm{Aa}$ \\
\hline 1800 & $58 \mathrm{Ba}$ & \multicolumn{2}{|c|}{$57 \mathrm{Ca}$} & $90 \mathrm{Bb}$ & $94 \mathrm{Ba}$ & \multicolumn{2}{|r|}{$23.0 \mathrm{Cb}$} & $24.8 \mathrm{Aa}$ \\
\hline 2400 & $49 \mathrm{Bb}$ & \multicolumn{2}{|c|}{$56 \mathrm{Ca}$} & $85 \mathrm{Cb}$ & $91 \mathrm{Ba}$ & \multicolumn{2}{|r|}{$22.0 \mathrm{Cb}$} & $24.5 \mathrm{Aa}$ \\
\hline $\mathrm{CV}(\%)$ & & 7.5 & & & & & 5.1 & \\
\hline
\end{tabular}


Table 4. Length of the seedling shoot (SPL) of cultivar BRS 359 RR and germination (G) of cultivar BRS 284, treated with different spray volumes $\left(0,600,1200,1800\right.$ and $2400 \mathrm{~mL}$. $100 \mathrm{~kg}^{-1}$ of seeds).

\begin{tabular}{lcc}
\hline \multirow{2}{*}{ Volumes } & BRS 359 RR & BRS 284 \\
\cline { 2 - 3 } & STL (cm) & G (\%) \\
\hline 000 & $5.1 \mathrm{~B}$ & $93 \mathrm{~A}$ \\
1200 & $6.0 \mathrm{~A}$ & $91 \mathrm{~A}$ \\
1800 & $5.0 \mathrm{~B}$ & $64 \mathrm{~B}$ \\
2400 & $5.0 \mathrm{~B}$ & $67 \mathrm{~B}$ \\
\hline CV (\%) & $5.0 \mathrm{~B}$ & $70 \mathrm{~B}$ \\
\hline Means followed by the same letter do not differ by Tukey test at 5\% probability. & 6.5 \\
\hline
\end{tabular}

Table 5. Total length of seedling (STL), shoot length (SL) and root length (RL) of soybean seeds of cultivars BRS 359 RR and BRS 284 treated with different volumes of spray $(0,600,1200,1800$ and $2400 \mathrm{~mL}$. $100 \mathrm{~kg}-1$ of seeds) with and without application of the dry powder.

\begin{tabular}{|c|c|c|c|c|c|c|}
\hline \multicolumn{7}{|c|}{----------- BRS 359 RR ------------ } \\
\hline \multirow{2}{*}{ Volumes } & \multicolumn{3}{|c|}{$\mathrm{STL}(\mathrm{cm})$} & \multicolumn{3}{|c|}{$\mathrm{RL}(\mathrm{cm})$} \\
\hline & With & \multicolumn{2}{|c|}{ Without } & With & \multicolumn{2}{|c|}{ Without } \\
\hline 0 & $14.4 \mathrm{Aa}$ & \multicolumn{2}{|c|}{$15.1 \mathrm{Aa}$} & $9.3 \mathrm{Aa}$ & \multicolumn{2}{|c|}{$9.9 \mathrm{Aa}$} \\
\hline 600 & $15.6 \mathrm{Aa}$ & \multicolumn{2}{|c|}{$15.8 \mathrm{Aa}$} & $9.5 \mathrm{Aa}$ & \multicolumn{2}{|c|}{$9.8 \mathrm{Aa}$} \\
\hline 1200 & $12.7 \mathrm{Ba}$ & \multicolumn{2}{|c|}{$13.1 \mathrm{Ba}$} & $7.6 \mathrm{Ba}$ & \multicolumn{2}{|c|}{$8.0 \mathrm{Ba}$} \\
\hline 1800 & $12.2 \mathrm{BCb}$ & \multicolumn{2}{|c|}{$13.1 \mathrm{Ba}$} & $7.0 \mathrm{BCb}$ & \multicolumn{2}{|c|}{$7.9 \mathrm{Ba}$} \\
\hline 2400 & $10.6 \mathrm{Cb}$ & \multicolumn{2}{|c|}{$11.6 \mathrm{Ca}$} & $5.8 \mathrm{Cb}$ & \multicolumn{2}{|c|}{$6.5 \mathrm{Ca}$} \\
\hline CV (\%) & \multicolumn{3}{|c|}{6.0} & \multicolumn{3}{|c|}{8.9} \\
\hline \multicolumn{7}{|c|}{ 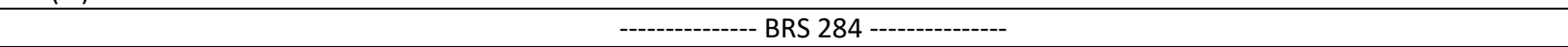 } \\
\hline \multirow{2}{*}{ Volumes } & \multicolumn{2}{|c|}{$\mathrm{STL}(\mathrm{cm})$} & \multicolumn{2}{|c|}{$\mathrm{SL}(\mathrm{cm})$} & \multicolumn{2}{|c|}{$\mathrm{RL}(\mathrm{cm})$} \\
\hline & With & Without & With & Without & With & Without \\
\hline 0 & $15.7 \mathrm{Ab}$ & $18.9 \mathrm{Aa}$ & $4.7 \mathrm{Bb}$ & $5.3 \mathrm{Aa}$ & $11.0 \mathrm{Ab}$ & $13.6 \mathrm{Aa}$ \\
\hline 600 & $13.9 \mathrm{Bb}$ & $15.9 \mathrm{Ba}$ & $5.6 \mathrm{Aa}$ & $5.2 \mathrm{Aa}$ & $8.3 \mathrm{Bb}$ & $10.7 \mathrm{Ba}$ \\
\hline 1200 & $12.7 \mathrm{Ba}$ & 13.8 Ba & $4.8 \mathrm{Ba}$ & $5.2 \mathrm{Aa}$ & 7.9 Ba & $8.6 \mathrm{Ca}$ \\
\hline 1800 & $12.5 \mathrm{Ba}$ & 13.5 Ba & $5.2 \mathrm{ABa}$ & $5.3 \mathrm{Aa}$ & 7.3 Ba & $8.2 \mathrm{Ca}$ \\
\hline 2400 & $13.5 \mathrm{Ba}$ & $13.8 \mathrm{Ba}$ & $5.1 \mathrm{ABa}$ & $5.1 \mathrm{Aa}$ & $8.4 \mathrm{Ba}$ & $8.8 \mathrm{Ca}$ \\
\hline CV (\%) & \multicolumn{2}{|c|}{9.9} & \multicolumn{2}{|c|}{6.7} & \multicolumn{2}{|c|}{13.8} \\
\hline
\end{tabular}

Means followed by the same letter, lowercase in the row and upper case in the column do not differ from each other by Tukey test at $5 \%$ probability

Therefore, the spray volumes reduced seedling emergence values compared to the values obtained in the germination test, since lower germination rates were occurred with the application of volumes of $1200 \mathrm{~mL} 100 \mathrm{~kg}^{-1}$ or higher in the seeds not treated with dry powder in BRS 359 RR. The seedling emergence in sand showed lower germination rates only with the application of a volume of $2400 \mathrm{~mL} 100 \mathrm{~kg}^{-1}$. This difference may be related to the substrate, in which the tests were conducted. In the germination test, the paper substrate may aggravate the phytotoxic effect of the products on the seedlings due to the constant contact of the chemicals applied to the seed coat with the primary root and coleoptile, structures of the seedlings that are under development during germination, causing abnormalities that affect the result of the test. However, in seedling emergence in sand substrate, this contact is minimized, since the seed coat is eliminated on the sand substrate during the germination process, not coming into direct contact with the seedlings during emergence. Also, the application of the dry powder reduced the emergence of seedlings in the two cultivars, at all spray volumes, except for the control treatment (volume 0) (Table 3).

\section{Seedling emergence speed index}

Seeds treated with dry powder showed lower seedling emergence speed when higher spray volumes were applied in both cultivars (Table 3). The seeds of BRS 359 RR not treated with the dry powder showed decreased speed of emergence with application of the volumes of 1200,1800 and $2400 \mathrm{~mL} 100 \mathrm{~kg}^{-1}$, whereas for cultivar BRS 284 there was no significant difference ( $p \leq 0.05)$.

Comparison of treatments with and without dry powder showed similar behaviors for both cultivars and the control treatment (volume 0), which was a higher emergence speed for the seeds treated with dry powder (Table 3). However, when the spray volumes were applied, the seeds not treated with dry powder showed a higher emergence speed. These results corroborate with those demonstrating the efficiency of this test. According to Krzyzanowski et al. (1999) and Schuab et al. (2006) an efficient vigor test must be related with germination and emergence values of the seedlings, as these are standardized parameters to estimate seed behavior under laboratory controlled conditions and uncontrolled field conditions.

\section{Total length of the seedling shoots and roots}

Regarding total seedling length data, there was interaction between the factors for the two cultivars (Table 2). Seeds treated with and without dry powder showed decrease in seedling length with the application of $1200 \mathrm{~mL} \mathrm{~kg}^{-1}$ and 600 $\mathrm{mL} 100 \mathrm{~kg}^{-1}$ or higher for cultivars BRS 359 RR and BRS 284, respectively (Table 5).

In cultivar BRS 359 RR, the seeds not treated with dry powder showed higher total length compared to those treated with dry powder after application of 1800 and 2400 $\mathrm{mL} 100 \mathrm{~kg}^{-1}$ (Table 5). For cultivar BRS 284, there were differences after application of the volumes 0 and $600 \mathrm{~mL}$. 
$100 \mathrm{~kg}^{-1}$. However, the seeds not treated with the dry powder showed better results.

For the shoot length of the BRS 359 RR cultivar, there was an isolated effect for spray volumes (Table 2). Larger shoot length was observed in the seedlings originated from seeds treated with the volume of $600 \mathrm{~mL} 100 \mathrm{~kg}^{-1}$ (Table 4). For cultivar BRS 284, a similar result was observed in the seeds treated with dry powder, whereas for the seeds not treated with dry powder there was no difference between the volumes (Table 5). The seeds not treated with dry powder had higher shoot length compared to those treated with dry powder for volume 0 (control).

In cultivar BRS 359 RR, the lowest values of root length were observed after application of 1200, 1800 and $2400 \mathrm{~mL} 100$ $\mathrm{kg}^{-1}$ for both the seeds treated and not treated with dry powder. Regarding the application of dry powder, the seeds not treated with dry powder had higher root length with the application of 1800 and $2400 \mathrm{~mL} 100 \mathrm{~kg}^{-1}$. For cultivar BRS 284 , lower root length values were observed with the application of volumes of $600 \mathrm{~mL} 100 \mathrm{~kg}^{-1}$ or higher. Moreover, higher length values were observed for seeds not treated with dry powder with the application of volumes 0

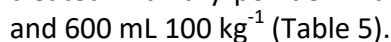

In general, the two cultivars showed a similar response to the seed treatment with the different volumes of spray and application of a dry powder. A negative interaction was observed between the dry powder and the spray volumes, with decrease in the physiological quality of the seeds. Therefore, further studies that allow greater accuracy in decision-making regarding the choice of the appropriate volume of spray, as well as the use of technologies associated with the treatment, e.g. dry powder and its effects on seed quality are required.

\section{Materials and Methods}

The experiment was conducted at Seeds and Grains Technological Center, of Embrapa Soybean, Londrina, Paraná, at the Laboratory of Seed Physiology and Technology.

\section{Treatments}

A completely randomized experimental design was performed with four replications in a $5 \times 2$ factorial arrangement. The factors consisted of five spray volumes used in seed industrial treatment $(0,600,1200,1800$ and $2400 \mathrm{~mL} .100 \mathrm{~kg}^{-1}$ of seeds) and application of a dry powder

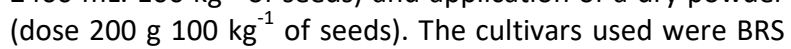
359 RR and BRS 284, which were separately analyzed. The maximum volume to be used was determined for the calculation of the different spray volumes. Then, the other volumes were obtained by reducing the doses of biostimulant, polymer, inoculant and micronutrient (Table 1). The products used were: F: fungicides (carbendazim + thiram); I: insecticides (imidacloprid + thiodicarb); $\mathrm{N}$ : nematicide (abamectin); $\mathrm{M}$ : micronutrients (cobalt, molybdenum and zinc); $\mathrm{P}$ : polymer (peridiam); $\mathrm{B}$ : biostimulant (kinetin + gibberellic acid, such as GA3 + 4indole-3-ylbutyric acid) and IN: inoculant (Bradyrhizobium japonicum). Seed treatment was performed with the aid of a BMC machine (Batch Modular Coater), similar to those used in industrial treatment of seeds, but designed for smaller seed sizes.

\section{Traits measured}

After the treatment, the physiological quality of the seeds was determined through the following assessments: Germination: performed with two subsamples of 50 seeds per replicate, totaling 400 seeds per treatment. The seeds were distributed on germitest paper towel rolls, moistened with distilled water, in a volume equivalent to 2.5 times the mass of the dry substrate. Thereafter, the rolls were placed in a seed germinator at a temperature of $25^{\circ} \mathrm{C}$. Germination count was performed on the eighth day, according to the Rules for Seed Analysis (Brasil, 2009). The percentage of normal seedlings was computed. First count of the germination test: performed concomitantly with the germination test. The count was performed on the fifth day after the beginning of the test. The percentage of normal seedlings was computed (Brasil, 2009). Seedling emergence in sand: performed with 800 seeds per treatment, divided into two subsamples of 100 seeds for each replicate. The seeds were sown on plastic trays using sand as substrate. The test was conducted in greenhouse conditions and the substrate moisture was maintained with irrigations, according to the crop needs. Assessment of the number of normal emerged seedlings was performed on the 12th day and the results were expressed as a percentage. Germination speed index: performed simultaneously with the germination test. Seedlings were assessed daily from the day that the first seedlings emerged, and the assessments were made until the twelfth day after sowing. Calculation of the emergence speed index was made with the equation suggested by Maguire (1962): $\quad$ IVE $=\mathrm{N} 1 / \mathrm{D} 1+$ $\mathrm{N} 2 / \mathrm{D} 2+\mathrm{Nn} / \mathrm{Dn}$, where $\mathrm{N} 1=$ number of seedlings emerged on the first day; $\mathrm{Nn}=$ accumulated number of emerged seedlings; $D 1=$ first day of counting; $D n=$ number of days counted after sowing. Total length of the seedling shoot and root: five subsamples of 20 seeds each were used per replicate, totaling 400 seeds per treatment. The seeds were distributed on paper towel rolls moistened with distilled water in a volume equivalent to 2.5 times the mass of the dry substrate and then placed in a seed germinator at a temperature of $25{ }^{\circ} \mathrm{C}$ for five days (Nakagawa, 1999). Subsequently, the total length of shoot and root of the normal seedlings was determined using a millimeter ruler, and the results were expressed in $\mathrm{cm}$ per seedling.

\section{Statistical analysis}

Data was submitted to Shapiro-Wilk and Hartley tests for assessment of normality and homoscedasticity, respectively. There was no need to transform the variables. Analysis of variance (ANOVA) was performed and the means were compared by Tukey's test at $5 \%$ probability. The Statistical Analysis Software Sisvar was used for ANOVA (Ferreira, 2011).

\section{Conclusions}

The seeds of both cultivars not treated with dry powder, showed lower germination rates in treatments with volumes equal or greater than $1200 \mathrm{~mL} 100 \mathrm{~kg}^{-1}$. The seeds of both cultivars not treated with dry powder show higher germination rates compare to the seeds treated with dry powder. 
For both cultivars the seedling emergence in sand was reduce with the increased spray volumes and with application of the dry powder. For the seeds not treated with dry powder in cultivar BRS 359 RR, only the application of $2400 \mathrm{~mL} 100 \mathrm{~kg}^{-1}$ and for cultivar BRS 284 the application of 1800 and $2400 \mathrm{~mL} 100 \mathrm{~kg}^{-1}$ reduced the seedling emergence in sand. In summary, increased spray volume associated with the application of dry powder in seed treatment reduced the physiological quality of soybean seeds, and spray volumes up to $1200 \mathrm{~mL} 100 \mathrm{~kg}^{-1}$ in seed treatment without the application of dry powder did not impact the emergence and establishment of soybean seedlings.

\section{Acknowledgments}

We would like to thank the Coordenação de Aperfeiçoamento de Pessoal de Nível Superior (CAPES) for granting scholarships to the first, second and fourth authors and the Brazilian Agricultural Research Corporation (EMBRAPA) for the facilities and financial aid provided for developing this study.

\section{References}

Abati J, Zucareli C, Foloni JSS, Henning FA, Brzezinski CR, Henning AA (2014) Treatment with fungicides and insecticides on the physiological quality and health of wheat seeds. J Seed Sci. 36:392-398.

Anwar SA, Riaz S, Ahmad CA, Subhani MN, Chattha, MB (2013) Mycoflora associated with stored seeds of soybean. Mycopatholgy. 11:85-90.

Balardin RS, Silva FL, Debona D, Corte GD, Favera DD, Tormen NR (2011) Tratamento de sementes com fungicidas e inseticidas como redutores dos efeitos do estresse hídrico em plantas de soja. Cienc Rural. 41:11201126.

Barros RG, Barrigossi JAF, Costa JLS (2005) Efeito do armazenamento na compatibilidade de fungicidas e inseticidas, associados ou não a um polímero no tratamento de sementes de feijão. Bragantia. 64:459-465.

Brasil. Ministério da Agricultura, Pecuária e Abastecimento (2009) Regras para análise de sementes. Ministério da Agricultura, Pecuária e Abastecimento. Secretaria de Defesa Agropecuária. Brasília: MAPA/ACS, 395 p.

Brzezinski CR, Henning AA, Abati J, Henning FA, França Neto JB, Krzyzanowski FC, Zucareli C (2015) Seeds treatment times in the establishment and yield performance of soybean crops. J Seed Sci. 37:147-153.

Brzezinski CR, Abati J, Henning FA, Henning AA, França Neto JB, Krzyzanowski, FC, Zucareli C (2017) Spray volumes in the industrial treatment on the physiological quality of soybean seeds with different levels of vigor. J Seed Sci. 39:174-181.

Conceição GM, Barbieri APP, Lúcio AD, Martin TN, Mertz LM, Mattioni NM, Lorentz LH (2014) Desempenho de plântulas e produtividade de soja submetida a diferentes tratamentos químicos nas sementes. Biosci J. 30:17111720.
Clifton RA (1985) Talc and Pyrophyllite. Ch. in Mineral Facts and Problems, U.S. Bureau of Mines Bulletin 675.

Ferreira DF (2011) Sisvar: A computer statistical analysis system. Ciênc Agrotec. 35:1039-1042.

França Neto JB, Henning AA, Krzyzanowski FC, Henning FA, Lorini I (2015) Adoção do tratamento industrial de sementes de soja no Brasil, safra 2014/15. Inf Abrates. 25 (1): 26-29.

Krzyzanowski FC, Vieira RD, França Neto JB (1999) Vigor de sementes: conceitos e testes. 1 st edn. Abrates, Londrina. 4.

Krzyzanowski FC, Henning AA, França Neto JB, Lopes ION, Zorita MD, Costa NP (2007) Volume de calda com diferentes produtos para o tratamento de semente de soja e seu efeito sobre a qualidade fisiológica. Londrina: Embrapa Soja, 48 p. (Documents, 290).

Mapa. Ministério da Agricultura, Pecuária e Abastecimento (2013) Instrução Normativa № 45, de 17 de setembro de 2013. Anexo XXIII - Padrões para produção e comercialização de sementes de soja. http://apasem.com.br/site/wpcontent/uploads/padroesin 0452013.pdf (Access Dec, 02, 2018)

Marcos Filho, J (2015) Fisiologia de sementes de plantas cultivadas. Abrates, Londrina. $660 \mathrm{p}$.

Mertz LM, Henning FA, Zimmer PD (2009) Bioprotetores e fungicidas químicos no tratamento de sementes de soja. Cienc Rural. 39:13-18.

Nakagawa J (1999) Teste de vigor baseados no desempenho das plântulas. In: Krzyzanowski FC, Vieira RD, França Neto JB Vigor de sementes: conceitos e testes, 1 st edn. Abrates, Londrina. p. 2.1-2.24.

Maguire JD (1962) Speed of germination-aid in selection and evaluation for seedling emergence and vigor. Crop Sci. 2:176-177.

Reznikov S, Vellicce GR, González V, Lisi V, Castagnaro AP, Ploper, D (2016) Evaluation of chemical and biological seed treatments to control charcoal rot of soybean. J Gen Plant Pathol. 82:273-280.

Schuab SRP, Braccini ALB, França Neto JB, Scapim CA, Meschede DK (2006). Potencial fisiológico de sementes de soja e sua relação com a emergência das plântulas em campo. Acta Sci Agron. 28:553-561.

Segalin SR, Barbieri APP, Huth C, Beche M, Mattioni NM, Mertz LM (2013) Physiological quality of soybean seeds treated with different spray volumes. J of Seed Sci. 35:501509.

Sharma KK, Singh US, Sharma P, Kumar A, Sharma L (2015) Seed treatments for sustainable agriculture-A review. J Appl \& Nat Sci. 7:521-539.

Toledo MZ, Cavariani C, França Neto JB, Nakagawa, J (2010) Imbibition damage in soybean seeds as affected by initial moisture content, cultivar and production location. Seed Sci Technol. 38:399-408.

Zorato MF, Henning AA (2001) Influência de tratamentos fungicidas antecipados, aplicados em diferentes épocas de armazenamento, sobre a qualidade de sementes de soja. Rev Bras Sementes. 23:236-244. 